\title{
Profit motive faces stiff challenge
}

\section{Washington}

RUSSIAN weapons scientists are being asked to do something that their Western counterparts have done poorly, if at all - use their knowledge to stimulate their country's civilian economy.

The international science centre that Western nations are setting up in Moscow (see Nature 355, 756; 1992) is intended primarily to keep Russian weapons makers from going to work for potentially hostile countries by providing them with meaningful collaborations in science and technology (see accompanying story). But Robert Gallucci, a US Department of State official, told the Senate Foreign Relations Committee last week that another important goal is "to contribute to the process of converting the former Soviet command economy to a market economy".

Such a conversion would require the 20,000 or so scientists and engineers working at Russia's two major nuclear weapons laboratories to pursue fundamentally new areas of research. While Western officials say they hope to enlist the Russians in programmes involving nuclear reactor safety, environmental cleanup and technology that could lead to commercially viable products, these same officials admit that the Russians have no history of carrying out such work.

"It's hard to imagine how we will pull it off," says Ed Dowdy, a nuclear engineer with 20 years' experience in the weapons field now serving as science adviser to Gallucci, "but we're certainly going to try."

The United States and the European Community have each pledged $\$ 25$ million towards the centre, which was pro- expected to reach nearly $\$ 100$ million.

The governments involved in the centre hope that, through collaborations with the West, the Russian weapons makers will turn their country's swords into ploughshares. But they face formidable obstacles.

The first is that turning weapons technologies into products for the consumer is a tricky business. Despite several years of federal laws, directives from

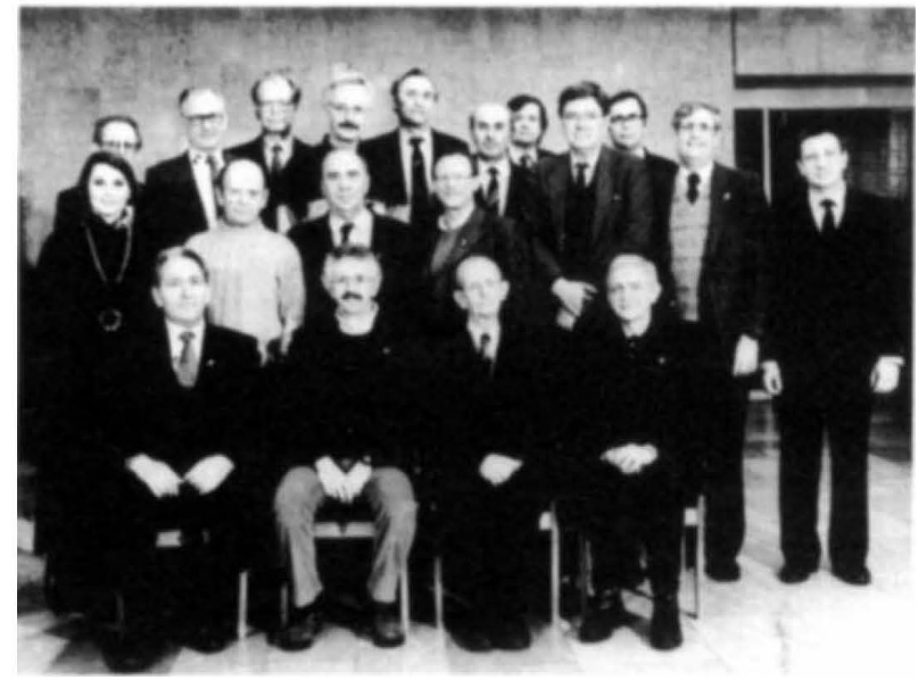

Visiting Arzamas, Sig Hecker (front row, 2nd from left) and John Nuckolls (front row, far right) pose with their weapons laboratory colleagues. the Bush administration and the active support of the US Department of Energy to do exactly that, the major nuclear weapons research facilities in the United States - the Lawrence Livermore, Los Alamos and Sandia national laboratories - have so far had little success.

For example, the tool preferred by the US government to forge such ties with industry, called a Cooperative $\mathrm{Re}$ search and Development Agreement (CRADA), has been barely used. Livermore announced its first CRADA only six weeks ago and Los Alamos has signed four such agreements, all within the past year. Sandia, which is deposed only last month and is expected to voted to the engineering aspects of makbe open by the early summer. Japan and Canada have also promised to contribute to a fund that, bolstered by money from industry and non-profit organizations, is ing weapons and conducts little pure research, has a slightly better track record, with some 18 CRADAs between itself and various companies.

\section{Politicians to call funding shots at the centre}

PEER review may be the hallmark of selecting worthwhile scientific projects in the United States and elsewhere. But do not look too hard for it at the new international science centre being set up in Moscow to employ Russian weapons makers and keep them from slipping off to work for potentially hostile countries.

Politicians will decide who works with the Russians after panels of scientists have eliminated ideas that lack sufficient technical merit. Moreover, many of those ideas will come from the governments that are putting up the money to fund the centre.

In testimony last week before the US Senate Foreign Relations Committee, US officials made it clear that their chief worry about the millions of dollars flowing into Russia's nuclear weapons laboratories is whether the money is going to the right people and whether they can watch it being spent. "As a member of the governing board of the centre, the US will be in a position to ensure that a substantial portion of the projects sponsored by the centre do, in fact, directly engage the weapons scientists and that all centre projects involve the necessary degree of transparency", explained Robert Gallucci of the US State Department. "The latter point is important to ensure adequate financial and programmatic monitoring of centre projects."
A recent report by the National Academy of Sciences (Nature 356, 181; 1992) urges the US government to create a director's fund so that staff can independently spend a portion of the centre's budget on what it thinks are the best ideas. Without such authority, the report says, the centre "will be seen as a needless and powerless middleman between proposers and funders".

That idea has not caught on within the Bush administration. Qualified scientists from around the world will be asked, by fax machine, to comment on proposals that have been submitted, according to Ed Dowdy, science consultant to Gallucci. But the awards, he says, will be made by "people of international stature, not broadly based in science, who are capable of making good decisions". Giving the director of the centre the authority to make awards "won't happen", he adds.

Gallucci told the US Senate that he has received more than 100 proposals to employ the weapons scientists since the centre was proposed scarcely a month ago. Most have come from government agencies, such as the Department of Energy. The proposals need not specify which scientists they wish to employ, Dowdy says; those that do not will be matched up with an appropriate research team.

J.D.M. 